\title{
The Latin Document Confirming the Date and Institution of Wilhem ten Rhyne's M.D.
}

By Robert W. Carrubba

Dr. Wilhem ten Rhyne (1649-1700), the celebrated Dutch physician and botanist, made major contributions to both Western and Oriental science: in 1678 his pioneering study of tea was published in Jacob Breyn, Exoticarum plantarum centuria prima $^{1}$; in 1683 his De Acupunctura ${ }^{2}$, the Western world's first detailed treatise on acupuncture, appeared; and in 1687 his classic report on leprosy, Verhandelingen van de Asiatise melaastsheid ${ }^{3}$, was printed. And we could cite additional works. Despite ten Rhyne's distinguished achievements, both the date and the institution from which he received his Doctorate of Medicine are regularly reported incorrectly. For example, in an otherwise useful account in the Dictionary of Scientific Biography (published in 1976) ${ }^{4}$ we are told that ten Rhyne received his medical degree from the University of Leiden in 1668 with his dissertation $D e$ dolore intestinorum a flatu. But in 1937, D. Schoute had already reported: “... there is a notice in the municipal archives of Amsterdam (Algemeen Nederlandsch Familieblad D. I, 1883/84 p.543) saying that Wilhelmus ten Rhyne took his degree on July 14th, 1670 at Andegavum (Angers)." ${ }^{5}$ As further evidence, a footnote informs us that a resident of Angers, Monsieur l'Abbé E. Pasquier sent a photograph of a document which he had discovered ${ }^{6}$. This document in Latin confirms Angers and 1670 as the institution and date of ten Rhyne's medical degree. Although Schoute printed a photograph of the ten Rhyne document, there has never appeared either a transcription of the Latin or a translation. Perhaps therein lies the reason for the persisting errors. Below are: (A) a photograph of the Latin document in the hand of ten Rhyne; (B) a transcription of the Latin; and (C) a translation. There can now be no doubt ten Rhyne received his Doctorate of Medicine from the University of Angers on July 14, 1670. 


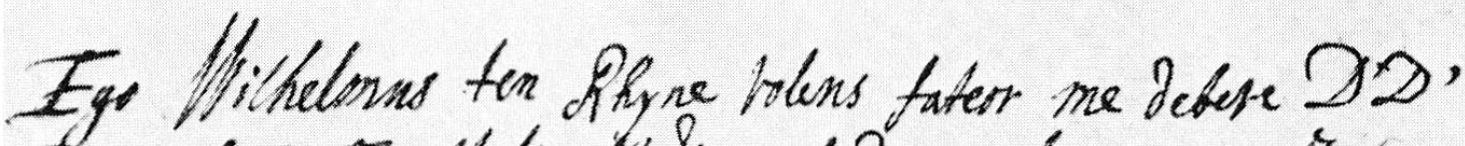

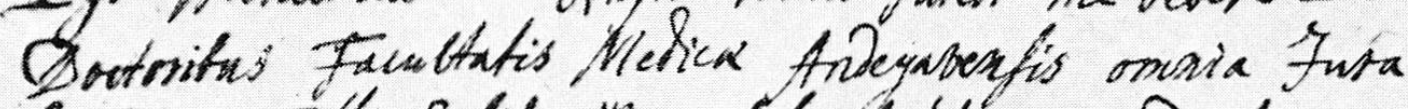

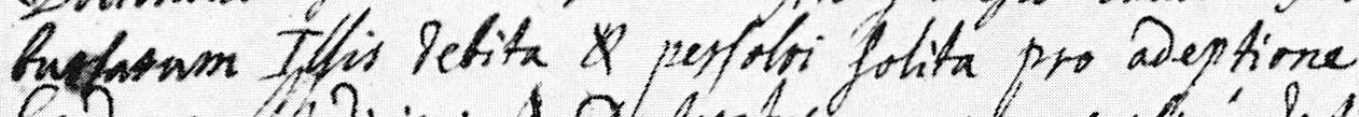

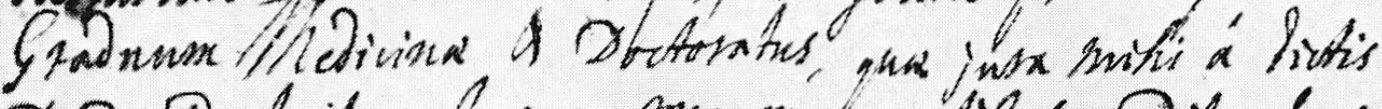

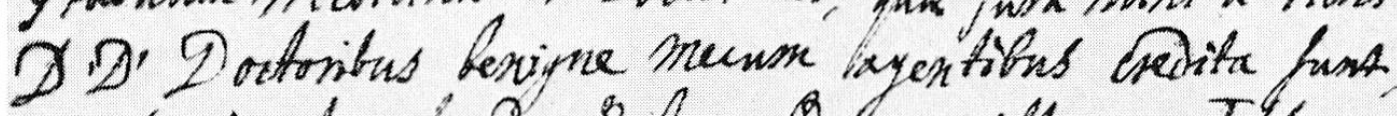

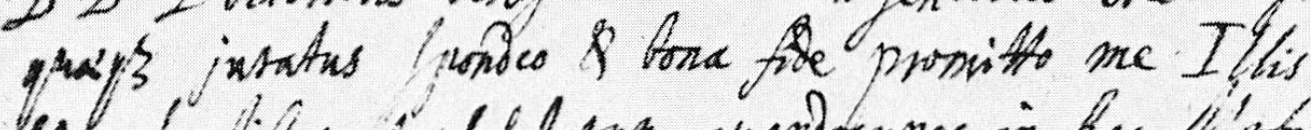

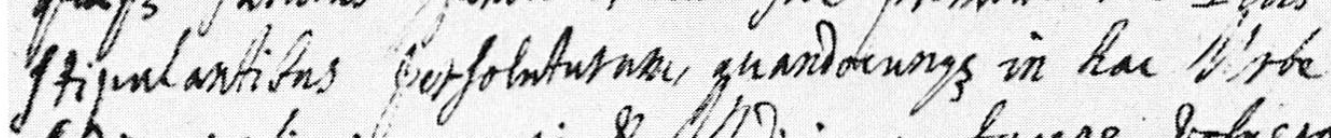

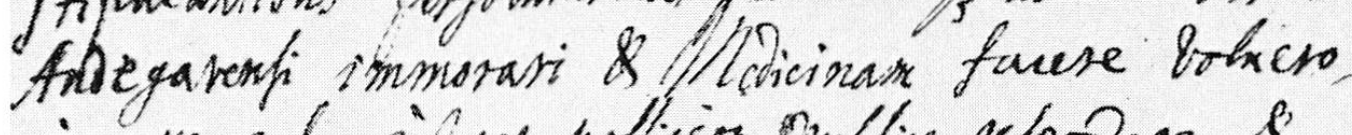

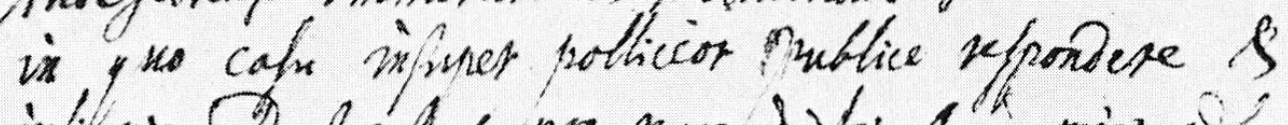

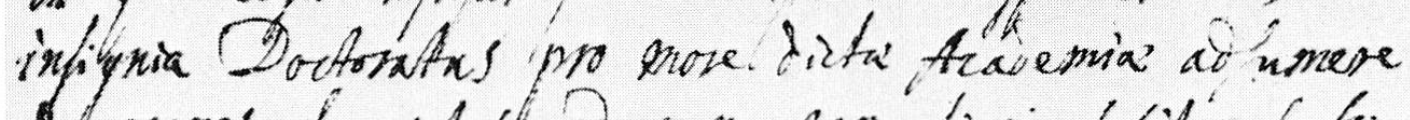

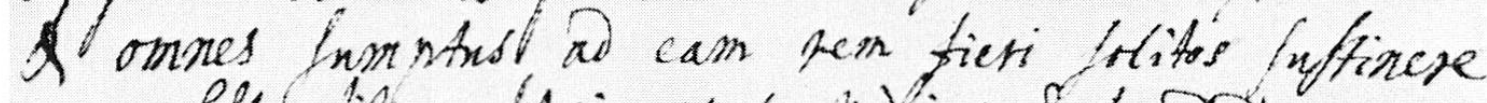

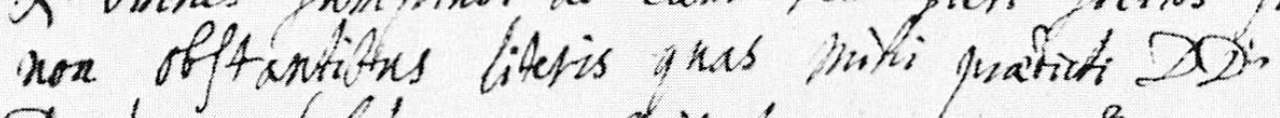

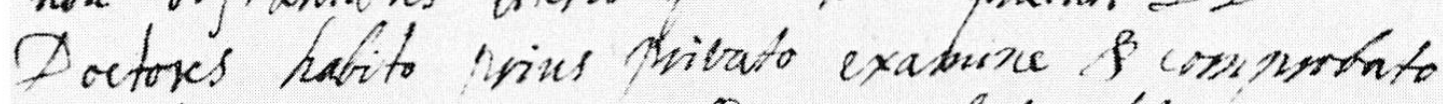
conceffenust, in cuins mi fidem pratentes listeris propria mann fublusipf:

if. sulis,

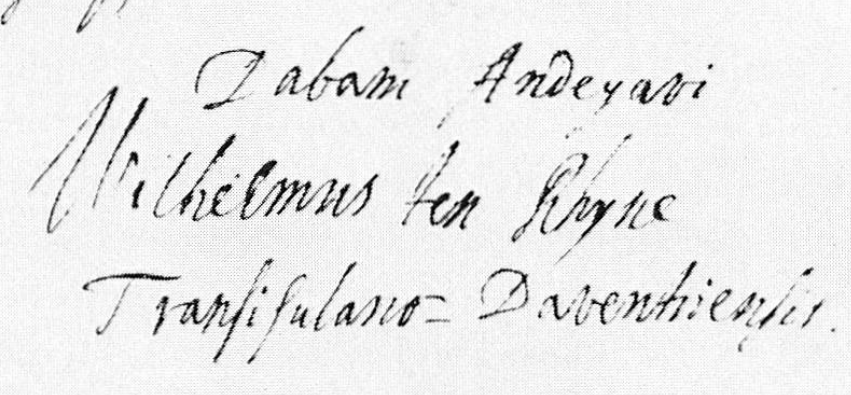

B. Transcription

Ego Wilhelmus ten Rhyne volens fateor me debere DD' Doctoribus Facultatis Medicae Andegavensis omnia jura bursarum Illis debita \& persolvi solita pro adeptione Graduum Medicinae \& Doctoratus, quae jura mihi a dictis 
DD' Doctoribus benigne mecum agentibus credita sunt, quaeque juratus spondeo \& bona fide promitto me Illis stipulantibus persoluturum, quandocumque in hac Urbe Andegavensi immorari \& Medicinam facere voluero, in quo casu insuper polliceor publice respondere \& insignia Doctoratus pro more dictae Academiae adsumere \& omnes sumptus ad eam rem fieri solitos sustinere non obstantibus literis quas mihi praedicti DD' Doctores habito prius privato examine \& comprobato concesserunt, in cujus rei fidem preasentes literas propria manu subscripsi.

\title{
14 Julii
}

1670

\author{
Dabam Andegavi \\ Wilhelmus ten Rhyne \\ Transisalano-Daventriensis
}

\section{Translation}

I Wilhelm ten Rhyne willingly confess that I owe to the Lord Doctors of the Medical Faculty of Angers all the obligations of the burses due to Them and usually fulfilled for the attainment of the Degrees of Medicine and the Doctorate, which obligations have been entrusted to me by the Lord Doctors dealing kindly with me, and which I pledge under oath and promise in good faith that I will fulfill as They stipulate, whenever I shall wish to reside and practice Medicine in this City of Angers, in which case I promise moreover to respond publicly and to assume the insignia of the Doctorate according to the custom of the aforementioned Academy and to sustain all the expenses accustomed to arise for this circumstance not withstanding the letter which the aforementioned Lord Doctors have granted to me on the basis of a previously administered private and confirmed examination, in faith of which matter I have signed the present letter with my own hand.

14 July

1670
I was writing at Angers

Wilhelm ten Rhyne

of Deventer in Overijssel 


\section{Footnotes}

1 Published in Danzig.

${ }^{2}$ Published in London and The Hague.

${ }^{3}$ Published in Amsterdam.

4 "ten Rhyne, Willem", by H.A.M. Snelders, Dictionary of Scientific Biography, vol.13, New York 1976, pp. 282-283. One should note that: The article gives 1647 as the date of birth but 1649 is correct; and the article spells his first name as Willem but Wilhem is the better spelling. Such errors are the rule in other scholarly works and have been committed by me in print.

${ }^{5}$ Opuscula Selecta Neerlandicorum de arte medica, vol. 14, Amsterdam 1937, p. XLIII.

${ }^{6}$ Ibid., footnote 3, p. XLIII.

\section{Zusammenfassung}

Ort und Datum der Verleihung des Doktortitels an den holländischen Arzt und Botaniker Wilhelm ten Rhyne wurden bisher in biographischen Handbüchern falsch angegeben. Carrubba reproduziert eine lateinische Urkunde mit Übersetzung ins Englische, aus der hervorgeht, daß ten Rhyne am 14. Juli 1670 in Angers den Doktortitel erhielt.

Robert W. Carrubba

Department of Classics

The Pennsylvania State University

University Park, PA 16802

USA 